\title{
Undergraduate Students
} as Collaborators in Building Student Learning Communities

\section{Candyce Reynolds}

Portland State University

Colleges and universities have recently used the concept of learning communities as a strategy to improve undergraduate student learning. This chapter describes a learning community approach where upper-division undergraduates serve as mentors for freshman and sophomore students and develop and sustain learning communities with faculty partners. The impact of this program is described and implications are discussed.

\section{INTRODUCTION}

Tncreasingly, colleges and universities are recognizing the importance of developing new curricular structures to enhance undergraduate student learning in response to criticism (e.g., Astin, 1993; Boyer, 1987; Coles, 1993) that higher education has not addressed the needs of a new generation of students. The Wingspread Group in Higher Education (1993) called for higher education institutions to build communities that develop an informed and involved citizenry that can assume leadership roles in American society. One strategy that colleges and universities have developed to meet this challenge is the creation of learning communities.

Shapiro and Levine $(1999$, p. 3) outline the following basic characteristics that define a learning community:

- Organizing students and faculty into smaller groups

- Encouraging integration of the curriculum 
- Helping students establish academic and social networks

- Providing a setting for students to be socialized to the expectations of college

- Bringing faculty together in more meaningful ways

- Focusing faculty and students on learning outcomes

- Providing a setting for community-based delivery of academic support programs

- Offering a critical lens for examining the first-year experiences

Colleges and universities have developed a variety of models that incorporate these characteristics into an institution's unique culture. For example, the University of Washington and the University of Oregon utilize a freshman interest group (FIG) program where students are involved in a living/learning environment (Bennett, 1999; Tinto \& Goodsell, 1993). Temple University and University of Maryland, College Park have developed learning community programs that address student needs through academic freshman seminar courses (Shapiro \& Levine, 1999). Other campuses, such as The Evergreen State College (Youtz, 1984) and Portland State University (White, 1998) integrate learning communities into their interdisciplinary general education curriculum. This chapter will describe the use of upper division undergraduate students in developing learning communities within its general education program at Portland State University (PSU) and discuss implications for other campuses.

\section{The Portland State University Model}

The faculty senate at PSU initiated a new general education program, University Studies, in 1994. A faculty working group developed the four-year general education plan based on higher education research on student success. The creation of intentional academic learning communities was at the forefront of the reform. Alexander Astin's work $(1992,1993)$ figured prominently in the development of the program as a whole, and specifically in the development of a student mentor program that involved using upper division students as mentors in support of the general education reform. Astin (1992, p. 30) described several factors that were correlated with positive effects in general education: 
- Student-student interaction

- Faculty-student interaction

- Discussing racial/ethnic issues with other students

- Hours devoted to studying

- Tutoring other students

- An institutional emphasis on diversity

University Studies was developed to address these issues within its curricular design. (See White [1994] for a more detailed description of the general education reform at Portland State University as a whole.)

The general education program at PSU spans across an undergraduate's entire academic career, starting with a year-long Freshman Inquiry and ending with a Senior Capstone, where interdisciplinary groups of students engage in a community-based learning course that addresses community issues. During the year-long freshman level course (Freshman Inquiry), undergraduate mentors are partnered with faculty to deliver these courses. In many other academic settings, a mentor is an experienced student who works with new students to aid in the adjustment to college. In our setting, the role of mentor is much broader. Mentors are role models, teachers, community builders, translators, and more. The use of these mentors has contributed to the success of the Freshman Inquiry program in ways that we had not anticipated at the inception of the program.

The role of peer mentor was created to enhance student experiences in these areas. Peer mentors were assigned to individual faculty teaching Freshman Inquiry. Peer mentors, who are upper-division undergraduates, attend the three-hour main section of the course and lead mentor sessions one hour twice a week with smaller groups of students. Originally, the primary role of mentor was to serve as a tutor of sorts for the main class. The mentor session would provide students opportunities to connect with each other in a smaller context and receive help from the mentors and fellow students on the coursework and in adjusting to college. As a student moved into Sophomore Inquiry, they would work with a graduate mentor in a similar fashion. (Students are required to take three interdisciplinary term-long courses to fulfill their Sophomore Inquiry requirement).

Portland State University's general education reform is entering its ninth year. Mentors have played an increasing role in transforming the curriculum, faculty practices, and students during this time. 


\section{The Current Role of the Mentor}

As mentioned earlier, the role of the peer mentor in Freshman Inquiry has evolved to include a multitude of tasks and functions. While being sensitive to the primacy of the faculty role in Freshman Inquiry, mentors now engage fully in a partnership with faculty to deliver the curriculum. Not only are they teachers, they are friends, facilitators of discussion and activities, technology trainers, role models, and guidance counselors.

During the first years of University Studies, it became evident that mentors were more than just tutors and guides. As with any institutional transformation process, the first years were a bit rocky. Faculty in Freshman Inquiry learned quickly that their mentors were valued colleagues in developing and delivering curriculum, managing classroom conduct, and providing collegial support as faculty endeavored to transform their own teaching strategies. Of significant importance in the first years, mentors served as a communication bridge between faculty and students aiding faculty and program administrators with valuable feedback on the impact of the program on students.

The mentor role today continues to be broad and multidimensional. As program administrators saw the role expanding, specific training and mentor support mechanisms were instituted. Currently, the program employs 45 upper-division undergraduate peer mentors and 38 graduate mentors. The positions are highly competitive and draw some of PSU's most talented and well-rounded students. Peer mentors are chosen for their academic skills (3.0 minimum GPA is required), interpersonal skills, problem solving skills, and commitment to program goals. At this point in the development of the University Studies program, the majority of the peer mentors have been enrolled in the University Studies general education classes and describe part of their motivation to be mentors as a way to give back to a program what was helpful in their own academic and personal development. Peer mentors receive a Laurel's Scholarship (a state-funded academic scholarship) that pays for their tuition and a small monthly stipend as compensation.

Writing an inclusive job description for mentors is difficult. All mentors are trained in collaborative/cooperative teaching methods, community building techniques, diversity education, teaching of writing, technology applications, and group/team development skills. Mentors are also trained in accessing campus and community resources. Minimally, mentors attend the main class sessions as an active participant in the course. Peer mentors meet with small groups of students twice a week for one hour. Faculty and mentors ideally meet at least once a week to plan curriculum and discuss course and student progress. Peer mentors have input into the mentor session portion of student grades. 
Because faculty and mentors enter into a partnership to work on a particular course, the role of the individual mentor is dependent on what each brings to the enterprise. In some ways, this is what makes the mentor program so unique and successful. There is not one correct way for a mentor to work. Faculty and mentors work together to create strategies that incorporate their personalities and strengths in order to contribute to their students' success. Mentors, in collaboration with faculty, often bring their unique talents and experiences into the classroom and the mentor sessions. For example, faculty can assign more complex technology assignments when they have a mentor who has extensive technology experience. A faculty member with an English major mentor can confidently assign peer review during the mentor session. Mentors often influence the choice of texts and assignments. Mentors always provide valuable feedback to the faculty member about how the course is being perceived by students and how the courses and assignments could be improved.

\section{Impact of the Mentor Program}

We have observed that the mentor program has had an enormous impact on the students, the faculty, and the mentors themselves. Again, it would have been hard to predict the breadth and extent of the impact of mentors at the inception of the program.

\section{Impact on Students}

Students often speak during focus groups and in their course evaluations about the role of their mentor in their success and comfort level at the university. As PSU is an urban institution that attracts first-generation college students or other nontraditional students, student retention and success is often dependent on how comfortable a student feels in this particular academic environment. Mentors, just by their presence, are strong role models of success in the university and a sign that students are valued by the university.

In addition, mentors role model and teach students academic coping skills. There are not many places today where students can get such pragmatic help as how to approach a complex text, how to read an assignment, and how to see the broader and personal implications of any given topic. Time and stress management are often topics of discussion, and mentors can speak from a uniquely current place about how to balance the multiple roles of a modern, urban student. Mentors share what does and does not work in academia.

Perhaps anyone new to a challenging endeavor (as in being a freshman university student) is likely to have difficulty interacting with those they perceive as having power over him or her. Mentors hear honest reflections from 
students about their experience at the university, in the class, and in their personal lives. Faculty in the first years were shocked by the information that their students shared with mentors about their lives, things they did not often hear about in other types of general education courses. Domestic violence, homelessness, mental illness, lack of parental support, and lack of academic preparation are all issues that mentors tend to learn about due to their in-between status. Knowing what a student is dealing with empowers both faculty and mentor to help the student, thus aiding in student academic progress.

Faculty also learned that students are much more likely to approach an inbetween person regarding their concerns about the course, the assignments, and their grade. The just-in-time feedback that mentors have been able to provide faculty has greatly enhanced student success in a course. How often do faculty explain away the lack of class enthusiasm and success to lack of motivation on the students' part? Mentors' timely, but diplomatic, feedback has enabled faculty to adjust their teaching to better meet students' needs.

Mentors also serve as a bridge to faculty by encouraging and modeling discussion with faculty. Students new to academia are often intimidated by faculty and have difficulty engaging the faculty-student interactions that are so important to their success. Mentors often walk that fine line between providing for the baby bird and nudging them out of the nest.

Students often describe finding a first friend at PSU in their mentor and making connections with fellow students in their Freshman Inquiry mentor sessions. In a large urban university that serves primarily commuter students, Freshman Inquiry, and especially the mentor sessions, offer some sense of home on campus.

\section{Impact on Faculty}

While this area has not been studied systematically, there is evidence that mentors have had a significant impact on faculty development. Many faculty have talked about the unique opportunity to have a "colleague" to discuss their course with. Often for the first time, faculty have someone they can muse with about why a certain student seems to respond adversely to certain content and why that lecture did not quite captivate their audience in the way they had planned.

Faculty report that their teaching and their own learning have improved because of their work with a mentor. The continuous feedback loop allows them to continually fine-tune their curriculum. Often, input from mentors allows faculty to see the topic of their course with a fresh eye. In addition, faculty report that they enjoy getting to know their students better through their input 
and the mentor's encouragement of students to use their office hours. Mentors help faculty reconnect with why they decided to teach in the first place.

\section{Impact on Mentors}

As with many peer helping programs, the greatest impact of the mentor program may be on the mentors themselves. While mentors, as a whole, are extremely successful students before they become mentors, they seem to become even better students. In spite of increased commitments and incredible challenges, mentors' GPAs, in general, improve. Mentors describe that mentoring forces them to organize themselves and their schoolwork. They have little free time and they also feel the pull to be an example for their students. Academics also seem to improve because not only are the students in the course learning to approach academic material in new ways, mentors are, too. They often describe understanding material at a much greater depth than they had previously.

Because mentors are aware of the goals of University Studies, they become keenly aware of the presence or lack of presence of these qualities in their own learning. Mentors report significant improvement in the achievement in the four University Studies goals. Mentors describe being better writers, better critical thinkers, and better citizens as part of being a mentor.

\section{Conclusion}

Learning communities have the potential of having a huge impact on student learning and retention as well as the way faculty approach student learning through their teaching (Shapiro \& Levine, 1999). Institutions of higher education need to continue to create models for developing learning communities that work on their individual campuses. Using undergraduates in building and sustaining learning communities is one way that institutions can tap into the rich resource in theit students, while contributing to faculty development and overall student learning. Although the Portland State University model may not be one that institutions can adopt completely, it seems important for institurions to seriously consider how they could use undergraduate students in building and sustaining learning communities. As one can see, the use of undergraduate and graduate mentors can have a far-reaching impact on students, faculty, and mentors themselves. 


\section{REFERENCES}

Astin, A. W. (1992). What really matters in general education: Provocative findings from a national study of student outcomes. Perspectives, 22 (1), 23-46.

Astin, A. W. (1993). What matters in college: Four critical years revisited. San Francisco, CA: Jossey-Bass.

Bennett, J. (1999). Learning communities, academic advising, and other support programs. In J. H. Levine (Ed.), Learning communities: New structures, new partnerships for learning. Columbia, SC: National Center for the First-Year Experience and Students in Transition.

Boyer, E. L. (1987). College: The undergraduate experience in America. New York, NY: HarperCollins.

Coles, R. (1993). The call to service: $A$ witness to idealism. Boston, MA: Houghton Mifflin.

Shapiro, N. S., \& Levine, J. H. (1999). Creating learning communities: A practical guide to winning support, organizing for change, and implementing programs. San Francisco, CA: Jossey-Bass.

Tinto, V., \& Goodsell, A. (1993). A longitudinal study of freshman interest groups at the University of Washington. University Park, PA: National Center for Postsecondary Teaching, Learning, and Assessment.

White, C. R. (1994). A model for comprehensive reform in general education: Portland State University. The Journal of General Education, 43 (3), 167-228.

White, C. R. (1998). Placing community-building at the center of the curriculum, Metropolitan Universities, 9(1), 55-62.

Wingspread Group in Higher Education. (1993). An American imperative: Higher expectations for higher education. Racine, WI: Johnson Foundation.

Youtz, B. (1984). The Evergreen State College: An experiment maturing, In R. M. Jones \& B. L. Smith (Eds.), Against the current. Cambridge, MA: Schenkman. 


\section{Contact:}

Candyce Reynolds

Director of Mentor Programs

Portland State University

17 PO Box 751-UNST

Portland, OR 97207

Voice (503) $725-8367$

Fax (503) 725-5977

Email reynoldsc@pdx.edu

Candyce Reynolds is the Director of Mentor Programs and Associate Professor in University Studies at Portland State University. A PhD in Counseling Psychology from the University of Oregon, she focuses her work with mentors and her scholarship on the development of reflective teaching practices. 